\title{
REMOTE INTERNET VOTING AND INCREASE OF VOTER TURNOUT: HAPPY COINCIDENCE OR FACT? THE CASE OF ESTONIA
}

\author{
by
}

KAREL SÁL *

Today's democracies (polyarchies) face a lowering trust of their own citizens towards democratic institutions, governments or fundamental processes like competition or participation. This common disappointment with democracy, which started around the 1960's in western democracies and manifested itself primarily by the lowering level of participation in elections, is frequently described as a "crisis of democracy" (Crozier, Huntington, Watanuki 1975). This trend worries politicians and political scientists because this low level of participation could undermine the very basis of democracy.

One possible solution comes along with the spread of new media and internet access as a common tool in the 1990's and mainly after the start of the new millennium: e-voting gets to be known as remote internet voting (RIV). The idea of overcoming the crisis of democracy by new media tools is based on a simple consideration: today's citizens are used to sort their matters on-line and the lowering demands for voting participation can bring new participants and boost the total turnout (see Blais, Gidengil, Nevitte 2004; Wattenberg 1998). Estonia ${ }^{1}$ today uses RIV for all level of elections. The number of usages generates a sufficient database for an analysis on how RIV can stand up to the expectations of increasing voter turnout.

karel.sal@e-politics.cz, Ph.D. Candidate in Institute of Political Research, Faculty of Social Sciences, Charles University, Prague, Czech Republic.

1 Switzerland uses remote internet voting for elections and referenda on all levels (federal, cantonal and local). Today RIV was used approximately in 174 cases. This will be the objective of further research. 


\section{KEY WORDS}

Remote Internet Voting, Estonia, Voter Turnout, Crisis of Democracy, Democracy

\section{VOTER TURNOUT AS A SIGN OF QUALITY OF DEMOCRACY}

From the scope of political science, one of most discussed topics in the theory of democracy is the role of the voter turnout in democratic elections and its correlation between the percentage of non-absentee voters and the quality of democracy. Meanwhile one group of theorists consider the voter turnout as an "excellent indicator" of quality of democracy for the unquestionable value and data purity (Lijphart 1994: 4; Lijphart 1999: 284). Another respected group of skeptics pointed out the methodological insufficiency related to this correlation and no clear data evidence of connection whatsoever (Lipset 1960, 1981; Sartori 1970, 1991).

We can agree with Seymour Lipset on that point - a low or high level of voter turnout itself does not reflect a good or bad sign for democracy, because the extension and the matter of participation is reflected by other yet undiscovered variables, which are more influential on the chances of a democratic system to maintain itself and develop (Lipset 1981: 229). Simply, voter turnout and the number of voter absentees cannot identify the quality of democracy in this vulgar postulate: higher turnout = better democracy.

Miroslav Novák argues in a similar manner and tries to point out, that there are too many deviant cases within Lijphart's approach. Some states with high voter turnout can be hardly considered as advanced democracies or polyarchies and on other side exemplary democracies as Switzerland record low voting participation for many years. Moreover, focusing simply on voter turnout does not reflect other important circumstances as compulsory voting, the type of voting system etc. (Novák 2011: 333; 1997) There is unfortunately still space to find these missing links between voter turnout and the quality of democracy, but that doesn't mean, that political science should not focus on the aspects of improving the voting process and its accessibility anymore. In fact, evaluating the effect of remote internet voting and e-democracy principles employment can either verify or falsify the expectations that are connected with the entrance of new media into the political process. After all, the idea of easier accessibility through new media isn't here only to help lazy voters, but to enable handicapped 
citizens, citizens living permanently abroad and others who would like to vote but can't, to cast their vote from anywhere around the globe.

\section{POSSIBILITIES HOW TO BOOST TURNOUT}

With the proliferation of new media and the Internet in the 1990's and mainly after the year 2000 a new possibility to deal with the spreading "crisis of democracy" has emerged. What Fareed Zakaria calls „increase of demands and lowering of trust" manifests itself very significantly from the 1960 's in an all-European manner mainly by a lowering voter turnout in all types of elections (Zakaria 2013). The dynamic of the voter turnout decline in European countries can be shown for example on the diminishing voter participation in European Parliamentary elections between the years 19792014.

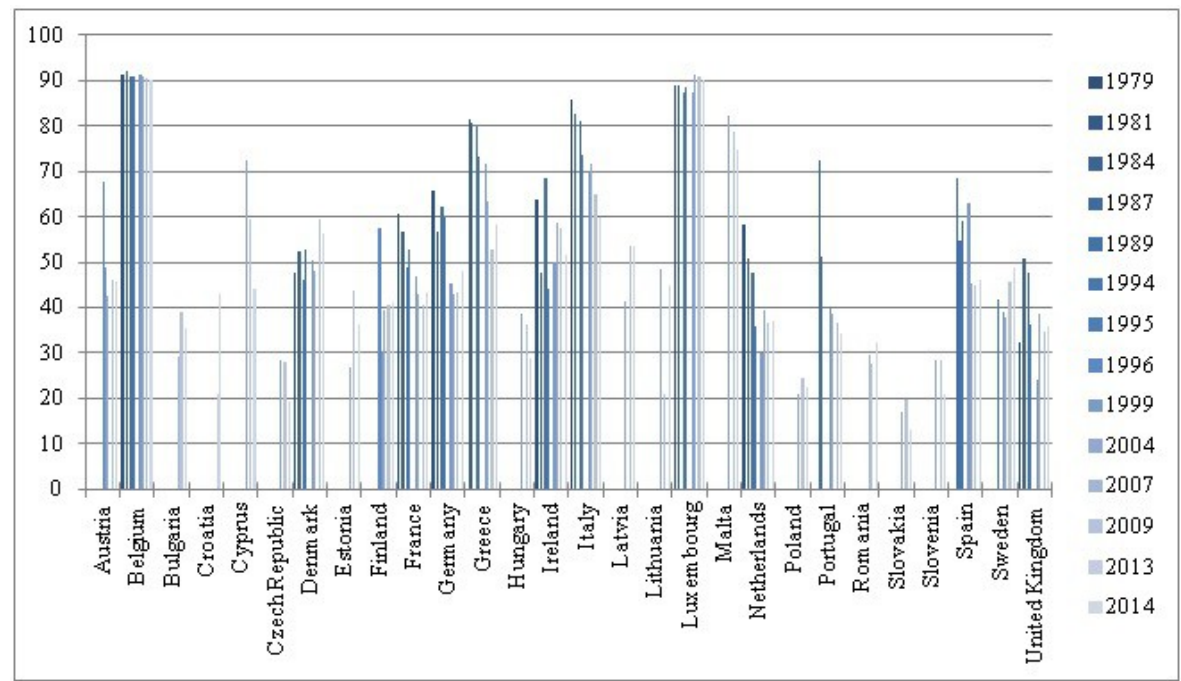

Diagram No. 1: Overview of turnout in European elections in 28 states between 1979-2014²

Diagram No. 1 shows, that in all EU countries the number of active voter diminishes persistently. From 28 countries in the diagram, only 4 member states: Belgium, Denmark, Luxembourg and the UK show radically different trends in the voter turnout in European elections. Belgium and Luxembourg still have a high percentage of active voters due to compulsory voting in these states. Denmark and mainly the UK show a low level of participation in the European election since the beginning of their

2 Data source: (European Parliament 2014, visited 2014-4-11). 
membership in the EU. Many governments have therefore due to this low turnout sought alternatives to standard voting techniques. For example in the UK, the historically lowest turnout in the 1997 national elections, when "only" $71.3 \%$ came to the polling stations (the least in the past 60 years), led the government to order a study about electronic voting and other voting alternatives (E21C 2002).

Initiatives stressing internet and electronic voting source their theoretic basis primarily from the classic economic theory known to the public as "costs and benefits theory". The fundamental axiom of this theory applied to voting is that the citizen decides rationally on whether or not to vote and acts in order with that decision. Expression in equation (Downs 1957: 260):

$$
U_{i}=P_{i} B_{i}-C_{i}
$$

"where the utility (Ui) of voting for an individual voter equals the benefits of the preferred outcome to the individual voter (Bi) times the probability that the vote will affect the outcome (Pi) minus the costs associated with voting (Ci). Based as any consumer purchase, people are hypothesized to consider both the costs and the benefits. If the benefits outweigh the costs, then the rational choice is to vote. Thus, if turnout is declining it must be because the benefits no longer outweigh the costs for many people" (Hobold, Klemmensen 2005: 4).

This approach was then highly stressed in national initiatives that promoted the institution of remote voting (e.g. Loncke, Dumortier 2004; Oostveen, Besselaar 2004). Their idea was based on the premise, that when the government lowers the costs for the potential voter (lowering $\mathrm{Ci}$ ), we can rationally expect, that at least a part of the electorate will return to participate, or that we can gain totally new voters. A theory of participation considered in such manner is in fact a simple synthesis of the resource theory, mobilization theory and specific context theory (Wattenberg 1998; Franklin 2002; Blais, Gidengil, Nevitte 2004). Lowering the demands and the rigidness of the voting process can attract a number of citizens and increase voter turnout.

Apart from electronic voting, in the sense of remote internet voting, that has not yet been sufficiently proven to raise voter turnout (Trechsel, 
Mendez 2002; Kersting, Baldersheim 2004; Reterová 2009; Alvarez, Hall, Trechsel 2009), other studies carried out in 31 states between 1945 and 1999 have shown, that introducing postal voting as an alternative to showing up at the polling station in person lead to an increase in voter turnout approximately by $5.5 \%$. For example in Switzerland, election results modeling in each particular canton has shown, that the increase in voter turnout between 1970 and 2005 was approximately 4.1\%. Single cases from Swiss cantos recorded even a hard to believe 15\% increase in turnout after introducing the postal vote (Leuchinger, Rosinger, Stutzer 2006). This positive outcome can be considered as a result of the lowering the barriers for potential voters.

Remote internet voting gives the voters similar benefits as postal voting. Compared to the other types of e-voting (Poll site voting and Kiosk voting) RIV enables voters to cast their ballots from any computer connected to the Internet from all around the world. Voting is not strictly limited to an area, where the election takes place. Therefore the voters who had been experiencing difficulties getting to the past elections, may now be able to practice their right as a citizen, which gives a solution to them, when they are abroad or when they are disabled. Also the voters who know that they won't be in town or are unable to visit an election site on the day of the election, may use a remote internet voting system to cast their votes. But for ordinary voters too a remote voting system will facilitate the casting of their ballots, as they can do so from any location connected to the internet (Oostveen, Besselaar 2004).

Form the scope of the costs and benefits theory, there is a high similarity between the postal vote and the remote internet voting principle. So how shall we determine and prove if remote internet voting really helps in increasing voter turnout?

\section{THE METHOD AND DATA}

This article is based on Lijphart's Theory Confirming Case Study (Lijphart 1979: 692) - on his analysis of a single instrumental case (elections with established RIV as an alternative) within the framework of the Dahl's concept of polyarchy (Dahl 1989). For revealing the efficiency of remote internet voting we have to focus on the so called voter turnout dynamics (Kostadinova 2003). Basically speaking, we are talking about a synchronous-diachronous comparison of the voter turnout evolution 
before and after introducing RIV as a voting alternative for different election levels. Possible occurrences of significant changes in total voter turnout before and after and changes (positive or negative) in the turnout of specific segments (users of alternative voting techniques vs. the traditional paper ballot) can alone be a sufficient proof of the effect that RIV has on voter turnout.

A significant difference, in opposition to other studies (e.g. Madise, Vinkel 2011), is in this study perceived as the moment, when the long-tern voter turnout trend shifts in the observed country. An arbitrary chosen borderline (e. g. a minimum of $3 \%$ ) is not suitable for this type of research, because when we have a negative trend in voter turnout, even a small change or halting the decreasing voter turnout (stagnation) after RIV introduction can be called a significant difference.

We will primarily focus on countries, that use RIV for their 1st and 2nd level elections and polls. The first country that employed remote internet voting into the voting process of a legislative body was Estonia. When completing the case study, it is therefore crucial to focus mainly on a wholesome analysis of voter turnout in time concerning the chosen case, where we also take in account other variables like the form of the voting process in the particular country, requirements posed upon the voters, other voting alternatives promoted by the government etc.

In the framework of RIV it is important to choose the particular cases in accordance with separate RIV projects. That means that if a country has one national voting electronization project, it can be analyzed as one particular case (that is the case of Estonia). In countries where the initiative and technical solution comes from lower units, it is necessary to analyze every single project and its efficiency separately (e.g. Switzerland and its initiatives coming from the cantonal level). ${ }^{3}$

Hypothesis are based on expectations of the outcome of RIV adoptions, that can be thoroughly identified in all national and sub-national initiatives that want to introduce RIV into the voting process (Loncke, Dumortier 2004: 60-61; Monnoyer-Smith 2006: 63-64):

Implementing RIV in Estonia after 2005 had a significant effect on raising voter turnout.

3 In Switzerland, cantons are primarily responsible for the development and implementation of RIV projects. That is based on the strong position of cantons in the federation. 
Data will be gained primarily from the national statistical office of Estonia (Vabariigi Valimiskomisjon) and from Eurostat. Other sources for data cross check are comparative analysis' from independent sources (e.g. IDEA) and national and supranational comparative studies.

\section{E-STONIA, FIRST IN THE ROW}

The Estonian electronic voting system was developed between 2002 and 2004, as a type of RIV, that enables the citizen to vote via the internet using an electronic ID (Eesti ID-kaart) and a special application form any place connected to the internet around the world (Breuer, Trechsel 2006). In January 2005, a first electronic referendum took place concerning the placement of a monument in Tallinn. In 2007, Estonia was the first state in the world to employ RIV for the election of 101 MPs of the national parliament (Riigikogu). In the last parliamentary elections in 2015, 176,328 Estonians voted via the internet (30.5\% of all actual voters), which is $19.6 \%$ of all eligible voters (VVKa).

To vote via the internet, the Estonian voter must have a special ID card, that besides other data contains an electronic signature of the holder. A voter who wishes to carry out his right to vote via the internet or outside his home voting district, must use the so called advanced voting. The electronic app opens to voters 10 days before the election day (Sunday) and closes 4 days before the election date - that means on Wednesday at 6 p.m. Election districts for a pre-vote through the traditional form open 6 days before election day (Monday) and close 4 days before (also Wednesday) at 8 p.m. During this period of time, the voter can log in the application using his special ID card and choose a political party based on his preferences. This vote can be changed several times before the closure of the access to the application (until Wednesday 6 p.m.) Nevertheless, the traditional paper ballot has higher priority. If the voter uses the paper ballot during the advanced voting period, this one is taken into the final account. After the 4 th day prior to election day a vote cast by alternative ways (via the internet or advanced voting stations) is considered valid and the citizen is no longer able to attend the polling station and cast vote on the standard election day on Sunday, because he was already crossed out from the list of voters (VVKb).

When we take a look at an overview of the Estonian voter turnout at national parliamentary elections and at European election form 1990 till 
today, we learn that the voter turnout in both elections continuously rises from 2003 (see diagram No. 2):

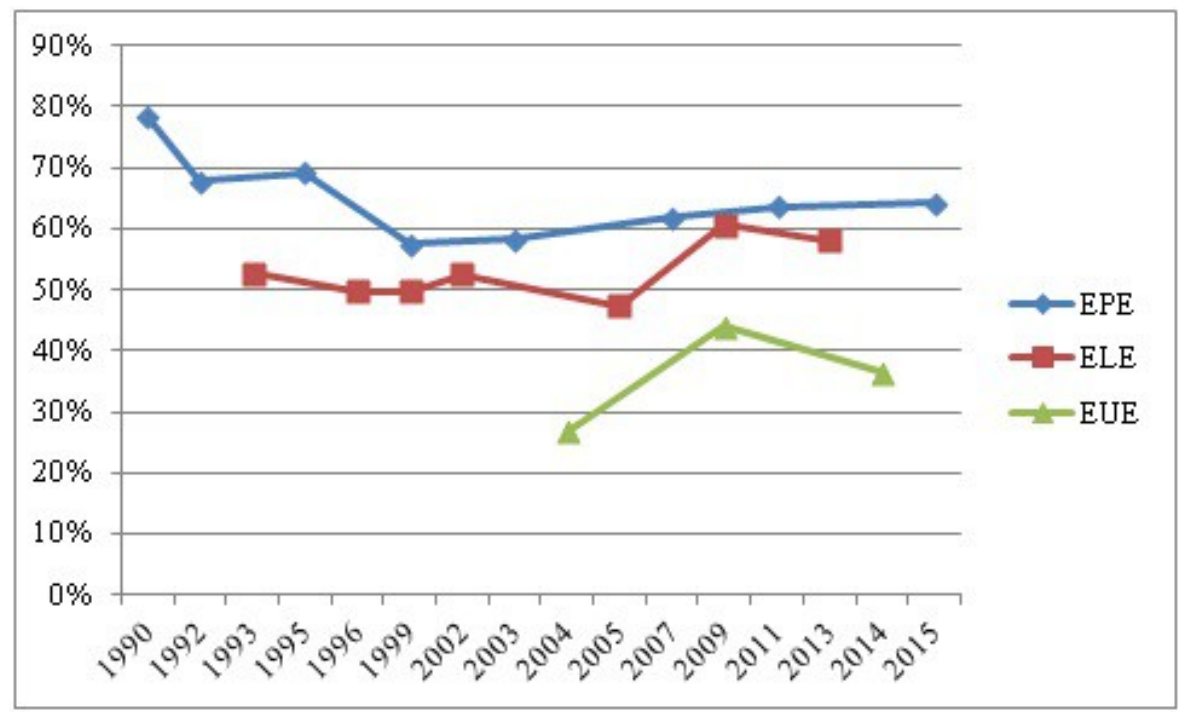

Diagram No. 2: Estonian voter turnout in national (EPE), local (ELE) and European elections

$(\mathrm{EUE})^{4}$

In 1990, we can interpret the voter turnout as a reaction to so called residual or mobilizing level. Residual voter turnout in former nondemocratic countries stays rather high in several subsequent elections due to long lasting mobilizing campaigns of the non-democratic regimes (Kostandinova 2003; Kostandinova, Power 2007, Bernhagen, March 2007). After a fall in the voter turnout in the 1990's, that took place also in other countries of the former Eastern Bloc (see more Kostadinova 2003: 749-754), in the course of 2003 the trends starts to shift in a positive dynamic. From this point of view it is hard to distinguish if that was due to the effect of evoting introduction, even though that during the period between 2003-2011 voter turnout rose by $5 \%$. It is also interesting to point out, that in the same period that RIV was introduced the number of invalid votes decreased rapidly.

For a more detailed evaluation of the effect that e-voting had on voter turnout we must start analysing particular elections that employed the RIV system. To this day Estonia has held (while not taking the pilot test of the referendum 2005 in account) 8 different election using RIV: 3 were

4 Data source: (VVKa; VVKb; IDEA 2015). 
parliamentary elections (2007, 2011 and 2015), 2 was a European election (2009 and 2014) and 3 were local elections (2005, 2009 and 2013). Particular types of elections have each a different voter participation dynamic, therefore it is crucial to research every type of election separately on their own level, comparing them with other elections on the same level that took part in the country without using an electronic alternative and advanced voting.

\begin{tabular}{|c|c|c|c|c|c|c|c|}
\hline $\begin{array}{c}\text { Type of } \\
\text { elections }\end{array}$ & Year & $\begin{array}{l}\text { Eligible } \\
\text { voters }\end{array}$ & $\begin{array}{l}\text { Total } \\
\text { votes }\end{array}$ & $\begin{array}{l}\text { Voter } \\
\text { turnout }\end{array}$ & Difference $^{5} \pm$ & I-voters & $\begin{array}{c}\text { I-voters/ } \\
\text { par. voters }\end{array}$ \\
\hline \multirow[t]{4}{*}{ Municipal } & 1993 & 880,296 & 463,443 & $52.6 \%$ & 0 & na & na \\
\hline & 1996 & 879,034 & 461,653 & $52.6 \%$ & 0.1 & na & na \\
\hline & 1999 & $1,052,404$ & 524,453 & $49.8 \%$ & 2.7 & na & na \\
\hline & 2002 & $1,021,439$ & 536,044 & $52.5 \%$ & 2.7 & na & na \\
\hline (RIV) & 2005 & $1,059,292$ & 502,504 & $47.4 \%$ & 5.1 & 9,317 & $1.9 \%$ \\
\hline (RIV) & 2009 & $1,094,317$ & 662,813 & $60.6 \%$ & 13.2 & 104,413 & $15.8 \%$ \\
\hline (RIV) & 2013 & $1,086,935$ & 630,051 & $58.0 \%$ & 2.6 & 133,308 & $21.2 \%$ \\
\hline \multirow[t]{5}{*}{ Parliamentary } & 1990 & $1,163,683$ & 900,001 & $78.2 \%$ & 0 & na & na \\
\hline & 1992 & 689,319 & 467,629 & $67.8 \%$ & 10.4 & na & na \\
\hline & 1995 & 791,957 & 545,771 & $68.9 \%$ & 1.1 & na & na \\
\hline & 1999 & 857,271 & 492,356 & $57.4 \%$ & 11.5 & na & na \\
\hline & 2003 & 859,714 & 500,686 & $58.2 \%$ & 0.8 & na & na \\
\hline (RIV) & 2007 & 897,243 & 555,463 & $61.9 \%$ & 3.7 & 30,275 & $5.5 \%$ \\
\hline (RIV) & 2011 & 913,346 & 580,264 & $63.5 \%$ & 1.6 & 140,846 & $24.3 \%$ \\
\hline (RIV) & 2015 & 899,793 & 577,910 & $64.2 \%$ & 0.7 & 176,328 & $30.5 \%$ \\
\hline European & 2004 & 873,809 & 234,485 & $26.8 \%$ & 0. & na & na \\
\hline (RIV) & 2009 & 909,628 & 399,181 & $43.9 \%$ & 17.1 & 58,669 & $14.7 \%$ \\
\hline (RIV) & 2014 & 902,873 & 329,766 & $36.5 \%$ & 7.4 & 103,151 & $31.3 \%$ \\
\hline
\end{tabular}

Data shows, that RIV is used by more and more voters. But shortly after its introduction in 2005, the usage of this possibility among the Estonian voters who exercised their right to vote was really low (not even $2 \%$ ). In the years to come, the number of voters via the internet slowly rises and reaches its peak with 176,000 participants in the 2015 parliamentary elections. The attractiveness of remote internet voting shows table No. 2

5 Difference between previous and actual turnout, red means decline, black increase.

6 Data source: (IDEA 2015; VVK 1993; VVK 1996; VVK 1999; VVK 2002; VVKa). 
below, where we can see, that the share of i-votes in the advanced voting framework becomes larger and larger. Recent 2015 parliamentary elections where the most "internety" due to a $30.5 \%$ share of total submitted votes via the internet and a $59.2 \%$ share of the advanced voting method used to cast a vote.

$\begin{array}{ll}\text { ELE 2005 } & 7.2 \% \\ \text { EPE 2007 } & 17.6 \% \\ \text { EUE 2009 } & 45.4 \% \\ \text { ELE 2009 } & 44 \% \\ \text { EPE 2011 } & 56.4 \% \\ \text { ELE 2013 } & 50.5 \% \\ \text { EUE 2014 } & 59.2 \% \\ \text { EPE 2015 } & 59.2 \%\end{array}$

Table No. 2: Proportion of i-votes among advance voters between 2005-2015

When we compare the number of $\mathrm{i}$-votes with the number of traditional ballots cast using the advanced voting principle, we get an overview the successfulness of alternative voting techniques in particular years and elections:

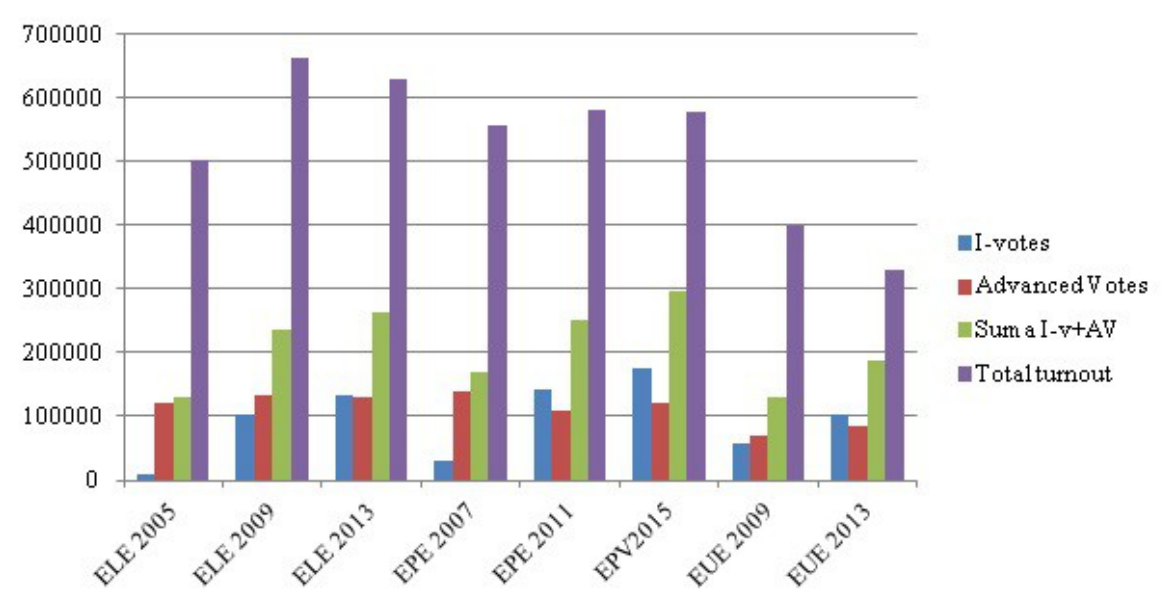

Diagram No. 3: Proportional number of i-votes and other advanced voting techniques compared with total turnout in elections $2005-2015^{8}$

\footnotetext{
ELE - local election; EPE - Parliamentary election; EUE - European election; Data source: (VVKa).

8 Data source: (VVKa)
} 
Concerning the voter turnout in different types and levels of elections, all elections after 2005 record a slight increase. From this point of view, the best overall results of RIV can be seen in municipal elections, where the turnout between 1993 and 2002 was stable and after introducing RIV in 2005 it even decreased. But after the 2009 elections we can record that significant growth (about 5\%) in voter participation using RIV, that the stonians confirmed in the last local elections. The number of articipating i-voters is continuously rising from 9,000 in 2005 to more than 130,000 in 2013. But connecting the number of $i$-voters and the rise in voter turnout isn't self-evident. As we saw in the last elections, even though the share of $i-$ voters is the highest ever $(133,000)$, the total voter turnout has slightly decreased. The number of voters that don't vote on the precise election day (RIV and advanced voting users) at the same time rises, while the proportion of the traditional ballot and the i-vote is changing.

A similar dynamic as seen on the example of municipal elections can be seen while examining the national parliamentary elections. Here the positive shift in the trend of voter turnout can be seen a little time before the RIV was actually introduced - the shift takes place between 1999 and 2003. In total figures we can see that the increase in this period is also about $5 \%$, which stands for 80,000 more participants, than in 2003. Alike in the local elections, the attractiveness of RIV to voters rises. In 2011 we can wee a significant development of internet voting at the expense of other techniques in the framework of advanced voting. Even in this case the increase of the number of i-voters doesn't copy an increase in the general voter turnout, but has a similar, even though not correlative, tendency.

Concerning European elections, we unfortunately have only a few cases. The first European elections didn't attract great interest among the Estonian voters. In 2009, their interest surprisingly rose (150,000 more voters), which with all the votes cast via the advanced voting principle shows a possible boost due to lowering the barriers for carrying out the vote. But the correlation between the number of $i$-voters and the total voter turnout was absolutely negated by the last European elections. Even though the proportion of voters using advanced voting was almost by a quarter higher than in the 2009 European elections, the total voter turnout decreased by $7.5 \%$. 


\section{DISCUSSION}

The outcomes of the analysis to a certain level copy the findings of past studies. I-voting in 2005 seems to have had a slight effect on the increase of voter turnout - voters sometimes vote and sometimes not. In 2007, approximately $10 \%$ of those i-voters where questioned and they said that they certainly or probably would not have voted without having had the possibility to vote using the internet (Madise, Vinkel 2011). Moreover, the survey showed that the percentage of the i-voters questioned who certainly or probably would not have voted without having had the possibility to vote via the Internet, has risen to $16.3 \%$, which can lead us to the conclusion that the overall turnout might have been as much as $2.6 \%$ lower in the absence of such methods of voting. That is already a significant marker when we take a look at the impact of internet voting on the overall voter turnout (Trechsel, Vassil 2010). Similar conclusions offer other and older analysis' (e.g. Buchstein 2004). All conclusions unfortunately lack a higher number of relevant and comparable case. This situation will become much better along with the promotion and introduction of internet voting in other democracies, that are preparing, installing or running pilot programs for RIV at the moment and in the future.

To enlighten the question of a potential turnout boost, we can compare the findings from a similar case of remote internet voting implementation in Norway. Some studies (e.g. Brunclík 2012; Baldersheim, Sagie, Segaard 2013) show, that the influence of RIV implementation in selected municipalities ${ }^{9}$ in local and regional elections in 2011 and in parliamentary elections ${ }^{10}$ in 2013 have no positive effect on the level of participation compared to other municipalities without the possibility of RIV usage. The total level of voting participation in the selected municipalities copied the turnout dynamic at other places in Norway without significant changes or discrepancies based on internet voting usage. However, the Estonian and Norwegian political system, culture and level of democracy are in many ways different, but the effects of RIV implementation on the turnout boost are quite similar (i.e. very low).

\footnotetext{
9 Bodø, Bremanger, Hammerfest, Mandal, Radøy, Re, Sandnes, Tynset, Vefsn and Ålesund.

10 Fredrikstad and Larvik joined to national pilot program in 2013.
} 


\section{CONCLUSION}

The analysis has shown, that a low number of relevant cases does not enable us to consider the influence of RIV on voter turnout. Estonia is one of a few countries that was able to incorporate principles of RIV voting into the traditional voting system in such a user friendly manner, that almost half of the population quickly adopted it. That is an unquestionable success.

In the case of Estonia the expectations associated with RIV, lowering of barriers for voters and the sought after effect of higher voter turnout were fulfilled only partially. The RIV system has good results on local and parliamentary elections, where we discover a significant change in the turnout trend by approximately $5 \%$ and higher participation due to the introduction of this voting alternative. In opposition, European elections didn't have a similar or stable dynamic, which stops us from further conclusions or sure predictions. Another folksy explanation is at hand - that when the citizen sees no point in the institution he is supposed to choose the representatives for, even a highly user friendly voting alternative won't change his mind in participating. The sought correlating relation between internet voting and the total voter turnout can't be convincingly proven. The data shows, that quick RIV adoption along with other alternative voting possibilities doesn't lead to an equal increase in voter turnout across different types and levels of elections. We can assume, that the majority of ivoters was and still is among the active voters, the only thing that really changes is their voting habits. A successful increase in voter turnout in Estonia should therefore be assigned more to lowering voting barriers, that to election electronization. The proven slight boost may sign, that the main positive influence on voter turnout was brought by more possibilities on how, when and where to vote. Lowering the barriers really brought new voters into the process, but if it was due to computerization, we cannot really say at this stage of research.

This concludes that RIV can theoretically help raising voter turnout, but only to a certain level, and moreover it causes the migration of voters form paper ballots to new voting techniques. On the other hand, RIV adoption diminished the number of invalid votes by three quarters (see IDEA 2015). 


\section{LIST OF REFERENCES}

Alvarez, M. R., Hall, T. E., Trechsel, A. (2009): Internet Voting in Comparative Perspective: The Case of Estonia. Political Science \& Politics. Vol. 42, No. 3, pp. 497-505.

Baldersheim, H., Sagie, J., Segaard, S. B. (2013): Internet Voting in Norway 2011: Democratic and Organizational Experiences. Oslo: Institute for Social Research.

Bernhagen, P., March, M. (2007): „Voting and Protesting: Explaining Citizen Participation in Old and New European Democracies." Democratization. Vol. 14, No. 1, pp. 44-72.

Blais, A., Gidengil, E., Nevitte, N. (2004): "Where does turnout decline come from?" European Journal for Political Research. Vol. 43, No. 2, pp. 221-236.

Breuer, F., Trechsel, A. (2006): E-voting in the 2005 local elections in Estonia. Report for the Council of Europe. Florence. [online] http://www.coe.int/t/dgap/democracy/activities/ggis/evoting/evoting_documentation/PDFFinalReportCOE_EvotingEstonia2005.pdf (visited 2014-5-12).

Brunclík, M. (2012): „Mají internetové volby vliv na volební účast? Případová studie z Norska." Evropská volební studia. Vol. 7, No. 2, s. 101116.

Buchstein, H. (2004): Online Democracy. Is It Viable? Is It Desirable? Internet Voting and Normative Democratic Theory. In: Kersting, N., Baldersheim, H. (eds.): Electronic Voting and Democracy: A Comparative Analysis. Basingstoke: Palgrave Macmillan, pp. 39-58.

Crozier, M., Huntington, S. P., Watanuki, J. (1975): The Crisis of Democracy: On the Governability of Democracies. New York University Press. 
Dahl, R. A. (1989): Democracy and its Critics. New Haven, London: Yale University Press.

Downs, A. (1957): An Economic Theory of Democracy. New York: Harper Collins.

E21C 2002 - Elections in the $21^{\text {st }}$ Century: from paper ballot to e-voting (2002): Independent Commission on Alternative Voting Methods. London: Electoral Reform Society.

European Parliament (2014): Results of the European elections: Turnout and Final Results. [electoral data, online]

http://www.europarl.europa.eu/elections2014-results/en/turnout.html (visited 2014-4-11).

Franklin, M. N. (2002): “The Dynamics of Electoral Participation." In: LeDuc, L., Niemi, R. G., Norris, P.: Comparing Democracies 2. New Challenge in the Study of Elections and Voting. London. pp. 149-168.

Hobold, S. B., Klemmensen, R. (2005): Welfare to Vote: The Effect of Government Spending on Turnout. Paper prepared for presentation at the Comparative Study of Electoral Systems (CSES) 2005 Plenary Session, August 30-31 2005. Washington.

IDEA 2015 - Institute for Democracy and Electoral Assistance: (2015): Voter turnout data for Estonia. (last update February 2, 2015) [online] http://www.idea.int/vt/countryview.cfm?id=68 (visited 2015-5-5).

Kersting, N., Baldersheim H. (eds.) (2004): Electronic Voting and Democracy: a Comparative Analysis. Houndmills, Basingstote, Hampshire, New York: Palgrave Macmillan.

Kostadinova, T. (2003): "Voter turnout dynamics in post-Communist Europe." European Journal of Political Research. Vol. 42, pp. 741-759. 
Kostadinova, T., Power, T. J. (2007): “Does Democratization Depress Participation? Voter Turnout in the Latin American and Eastern European Transitional Democracies." Political Research Quarterly. Vol. 60, No. 3, pp. 363-377.

Leuchinger, S., Rosinger, M., Stutzer, A. (2006): The Impact of Postal Voting on Participation. Evidence for Switzerland. Working Paper No. 297. http://www.zora.uzh.ch/52253/1/iewwp297.pdf (visited 2014-5-9).

Lijphart, A. (1979): "Comparative Politics and the Comparative Method." The American Political Science Review, Vol. 65, No. 3, pp. 682-693.

Lijphart, A. (1994): “Democracies: Forums, performance and constitutional engineering." Journal of Political Research. Vol. 25, No. 1, pp. 1-17.

Lijphart, A. (1999): Patterns of Democracy. New Haven, London: Yale University Press.

Lipset, S. (1960/1981 exten.): Political Man. The Social Bases of Politics. Baltimore: John Hopkins University Press.

Loncke, M., Dumortier, J. (2004): “Online voting: A legal perspective." International Review of Law, Computers \& Technology. Vol.18, No. 1, pp. 6061.

Madise, Ü., Vinkel, P. (2011): “Constitutionality of Remote Internet Voting: The Estonian Perspective." Juridica Internacional. No. 13, [online] http://www.juridicainternational.eu/?id=14845 (visited 2014-5-9).

Monnoyer-Smith, L. (2006): "How I-voting technology challenges traditional concepts of citizenship: An analysis of French voting rituals." In: Krimmer, R. (ed.): Electronic Voting 2006. $2^{\text {nd }}$ International Workshop. Bonn: Gesellschaft für Informatik. pp. 63-64. 
Novák, M. (1997): “There is One 'Best' Model of Democracy?” Efficiency and Representativeness: 'Theoretical Revolution' or Democratic Dilemma?" Czech Sociological Review. Vol. 5, No. 2, pp. 131-157.

Novák, M. et al. (2011): Úvod do studia politiky. Praha: Slon.

Oostveen, A., Besserlaar Van Den, P. (2004): Internet Votic technologies and civic participation: The users' prerspective. The Public, Vol. 11, Amsterdam.

Reterová, S. (2009): Alternativní zpiosoby hlasování. Od tradičních voleb k online volbám. Olomouc: Perpilum.

Sartori, G. (1970): "Concept misinformation in comparative politics." The Americam Political Science Review. Vol. 64, No. 4, pp. 1033-1053.

Sartori, G. (1991): "Comparing and Miscomparing." Journal of Theoretical Politics. No. 3, pp. 243-257.

Trechsel, A., Mendez, F. (2004): The European Union and e-Voting. Adressing the European Parliament's internet voting challenge. London, New York: Routledge.

Trechsel, A., Vassil, K. (2010): Internet Voting in Estonia: A Comparative Analysis of Four Elections Since 2005. Council of Europe and European University Institute. [online] http://www.vvk.ee/public/dok/Report_-_Evoting_in_Estonia_2005-2009.pdf (visited 2014-5-11).

VVKa - Vabariigi Valimiskomisjon. Estonian National Electoral Committee: Statistics about Internet Voting in Estonia. [electoral data, online] http://www.vvk.ee/voting-methods-in-estonia/engindex/statistics (visited 2015-5-15).

VVKb - Vabariigi Valimiskomisjon. Estonian National Electoral Committee: Advance Voting. [electoral data, online] http://www.vvk.ee/votingmethods-in-estonia/voting-in-advance/ (visited 2015-5-15). 
VVK 1993 - Vabariigi Valimiskomisjon. Estonian National Electoral Committee: Kohaliku omavalitsuse volikogude valimine (17. oktoober 1993). [electoral data, online] http://vvk.ee/varasemad/?v=k93 (visited 2015-515).

VVK 1996 - Vabariigi Valimiskomisjon. Estonian National Electoral Committee: Kohaliku omavalitsuse volikogude valimine (20. oktoober 1996). [electoral data, online] http://www.vvk.ee/varasemad/?v=k96 (visited 2015-5-15).

VVK 1999 - Vabariigi Valimiskomisjon. Estonian National Electoral Committee: Kohaliku omavalitsuse volikogude valimine (17. oktoober 1999). [electoral data, online] http://www.vvk.ee/varasemad/?v=k99 (visited 2015-5-15).

VVK 2002 - Vabariigi Valimiskomisjon. Estonian National Electoral Committee: Kohaliku omavalitsuse volikogude valimine (20. oktoober 2002). [electoral data, online] http://www.vvk.ee/varasemad/?v=k02 (visited 2015-5-15).

Wattenberg, M., P. (1998): Turnout Decline in the U.S. and other Advanced Industrial Democracies. Irvine: University of California.

Zakaria, F. (2013): “Can America Be Fixed?" Foreign Affairs. [online] http://www.foreignaffairs.com/articles/138474/fareed-zakaria/canamerica-be-fixed (visited 2014-5-11). 